Tohoku J. exp. Med., 1965, 85, 317-329

\title{
Speleotomy in Renal Tuberculosis
}

\author{
By \\ Seigi Tsuchida \\ From the Department of Urology, Tohoku University School \\ of Medicine, Sendai; Director: Prof. S. Shishito \\ (Received for publication, August 4, 1964)

\begin{abstract}
Speleotomy was re-evaluated in the present study with the observations in 11 cases; and a modification of Staehler's operation, "cavity constriction", was introduced. Staehler's operation was carried out in 6 cases and "cavity constriction" in 5 cases. In most cases the presence of cavities in the kidney was suspected on the intravenous pyelograms, and it was confirmed by retrograde pyelography combined with pneumoretroperitoneum and by aortography. After the operation, improvement in urinary findings and in the renal function was noted in several cases. Irrespective of duration of chemotherapy, tuberele bacillus was demonstrated in the cavities of 6 cases. In all cases, where cavity constriction was carried out, postoperative fistula closed within 2 weeks, while in some cases where Staehler's operation was carried out, the fistula persisted much longer.
\end{abstract}

Speleotomy was carried out first in 1935 by Heitz-Boyer ${ }^{9}$ who reported a success in curing a closed cavity by resecting its free portion with a radio-knife. In those days, however, chemotherapy was not invented yet. Naturally, it was not taken up for a routine method, because of the danger of tuberculous spread to the surrounding tissues. In 1953, Staehler" re-introduced this technique as "Kavernotomie" at a congress of German Surgical Association. Since then, this operation has been widely employed for operative treatment of renal tuberculosis. After experiencing 7 cases, Aboulker and Wetterwald ${ }^{1}$ reported that this technique could be employed in serious cases in which partial nephrectomy was not indicated. Similar technique, named "Spéléotomie", is reported by Couvelaire ${ }^{3}$ in 1959 . Several reports on efficacy of speleotomy were issued since then. ${ }^{5,8}$ Further, Ljunggren ${ }^{13,14}$ stated that the operation produced an effect equal to that of partial nephrectomy against the closed cavity. Despite many reports on speleotomy not a few problems on its indication, technique and efficacy remain unsolved. Therefore, we re-evaluated speleotomy based on an observation in 11 cases, together with introducing a modification of Staehler's operation, "cavity constriction". 
1) Operation technique

(1) Staehler's operation

After being exposed by a lumbar oblique incision, the kidney is punctured with a fine injection needle at the portion where a cavity is suspected to exist. When the site of the cavity is ascertained by the puncture, an incision is given to its free portion, and its content is removed. After the cavity is dusted with streptomycin (SM) powder, an drainage tube is fixed inside the cavity. Then, the muscle and skin incisions are closed. After the operation, the fluid stored in the cavity space is removed through the tube every day, and SM solution is injected into it. The amount of the fluid usually decreases in 8 to 14 days, and then the drainage tube is taken off.

(2) "Cavity constriction"

This method resembles somewhat "Kollapsbehandlung" which Rehn'15,16
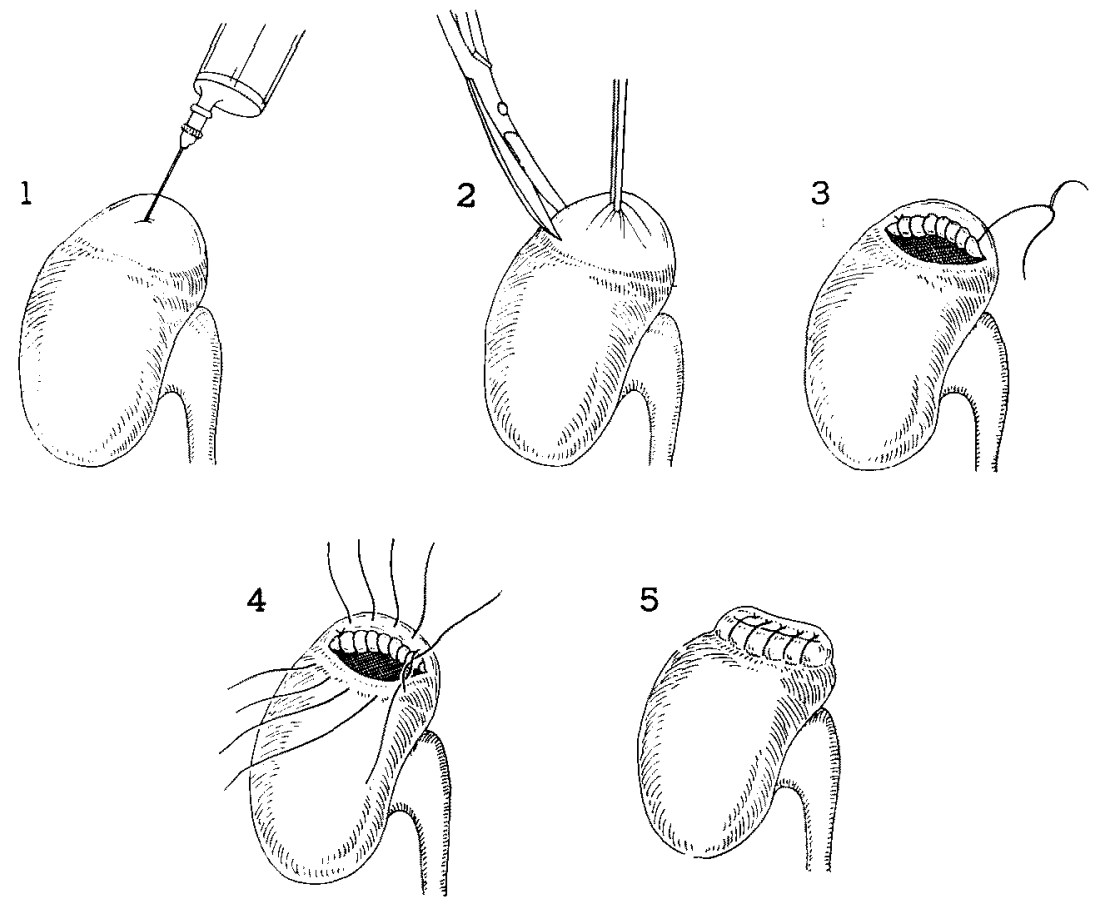

Fig. 1. Cavity constriction.

1) Puncture of the cavity with an injection needle to aspirate the cavity content.

2) Resection of the free portion of the cavity.

3) Uninterrupted suture of the excised cavity wall with a fine catgut.

4) Constriction of the cavity by interrupted sutures with catgut.

5) Cavity constricition is finished. 
carried out for open foci of renal tuberculosis, and Couvelaire's" "Spéléotomie". This operation shares its procedure with Staehler's in so far as determination of the site of the cavity. When an incision is given to the cavity, however, its free portion is profusely resected. When bleeding occurs, the edges of the excised cavity wall are sutured uninterruptedly with a fine catgut. Then, the cavity is deliberately scraped off as far as intact renal parenchyma appears. Bleeding which follows will be easily stopped by the subsequent suturing. When several cavities are found, the septa between them are to be removed. Sometimes, communications between the cavity and the renal pelvis or calyces are found at the operation, although the cavity looks closed roentgenologically. When communications are present, they are to be closed with fine catgut sutures. When these procedures are over, the cavity space is collapsed by placing interrupted mattress catugt sutures over the cavity incision. This procedure stops bleeding in the cavity, as well. Then, the muscle and skin incisions are closed, after inserting a drainage tube into the retroperitoneal cavity outside of the fibrous capsule (Fig. 1). After the operation, the drainage discharge is removed once a day with subsequent injection of SM into the tube. The discharge is usually small in amount, and the tube can be taken off in 5 to 6 days.

\section{2) Materials}

Eleven patients with renal tuberculosis in which speleotomy was performed were observed in the present study; Staehler's operation in 6 cases and "cavityconstriction" in 5 cases. The cases are shown in Table I. Prior to the present operation, Cases 3, 4, 5, 6 and 11 had undergone unilateral nephrectomy due to renal tuberculosis and Case 2 due to pyonephrosis. Case 1 had received ureterocystostomy due to ureteral stricture. Cases 1 and 4 had a complication of epididymal tuberculosis and Cases 8 and 10, bone-joint tuberculosis. On these patients pre- and postoperative courses were observed, intracavitary ${ }^{131}$ I-

Table I. Age, Sex, Diagnosis, Side of Operation and Complications

\begin{tabular}{|c|c|c|c|c|c|}
\hline Case & Age & Sex & Diagnosis & $\begin{array}{l}\text { Side of } \\
\text { operation }\end{array}$ & Complication \\
\hline 1 & 31 & Male & Tbc. of left kidney & Left & Tbc. of right epididymis \\
\hline 2 & 24 & Male & Tbe. of both kidneys & Right & - \\
\hline 3 & 49 & Female & Tbc. of left solitary kidney & Left & $\overline{1 \cdot}$ \\
\hline 4 & 39 & Male & Tbe. of left solitary kidney & $"$ & $\begin{array}{l}\text { Tbc. of bilateral } \\
\text { epididymides }\end{array}$ \\
\hline 5 & 37 & Female & Tbe. of left solitary kidney & $"$ & - \\
\hline 6 & 38 & " & Tbc. of left solitary kidney & $"$ & - \\
\hline 7 & 28 & $"$ & $\begin{array}{l}\text { Tbc. of both kidneys with } \\
\text { left ureteral stenosis }\end{array}$ & $"$ & - \\
\hline 8 & 42 & $"$ & Tbc. of both kidneys & $"$ & Bone-joint tbc \\
\hline 9 & 24 & $"$ & Tbc. of left kidney & $"$ & - \\
\hline 10 & 29 & $" \prime$ & Tbc. of left kidney & " & Bone-joint tbe. \\
\hline 11 & 35 & $"$ & Tbc. of right kidney & Right & - \\
\hline
\end{tabular}




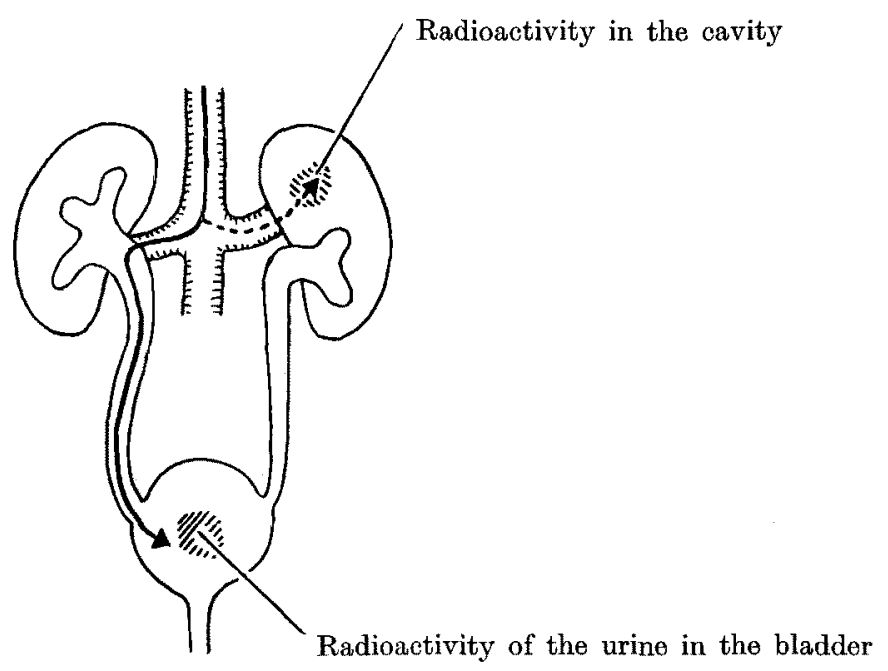

Fig. 2. Intracavitary ${ }^{131}$ I-hippuran excretion test.

One hundred $\mu \mathrm{c}$ of ${ }^{13}$ I I-hippuran was injected inravenously. The ratio of the radioactivity in the cavity and that of the intravesical urine accumulated during the operation is calculated.

hippuran excretion test, which was devised for intracavitary renal function, being performed. The procedure was as follows: $100 \mu \mathrm{c}$ of ${ }^{131}$ I-hippuran was injected intravenously twice, three hours before and at commencement of the operation. The radioactivity in the intracavitary content and that of urine in the bladder during the operation were measured with a Geiger-Müller counter, and a ratio of the former to the latter was obtained (Fig. 2).

(1) Age, sex, side of affection and complications

These are tabulated in Table $I$.

(2) Initial symptoms and chief complaints

As shown in Table II, pollakiuria and cloudy urine were the initial symptoms

TABLE II. Initial Symptoms and Chief Complaints

\begin{tabular}{c|l|l}
\hline Case & \multicolumn{1}{|c|}{ Initial symptoms } & \multicolumn{1}{|c}{ Chief complaints } \\
\hline 1 & Swelling of the right epididymis & $\begin{array}{l}\text { Dull pain in the right testicle } \\
\text { Hematuria }\end{array}$ \\
2 & Fever & $\begin{array}{l}\text { Discomfort in the left lumbar region } \\
\text { Left lumbago }\end{array}$ \\
4 & Pollakiuria & Left lumbago \\
5 & Cloudy urine & Pollakiuria \\
6 & Pollakiuria & Discomfort in the left lumbar region \\
7 & Pollakiuria & $?$ \\
8 & Arthralgia & Pollakiuria \\
9 & Pollakiuria & $?$ \\
10 & Arthralgia & Cloudy urine \\
11 & Pollakiuria &
\end{tabular}


TABLE III. Usability of X-ray Examinations in Diagnosis of Renal Cavity ( $O$ : The presence of a cavity was suspected) (O): The presence of a cavity was confirmed)

\begin{tabular}{r|c|c|c|l}
\hline Case & $\begin{array}{c}\text { Intravenous } \\
\text { pyelography }\end{array}$ & $\begin{array}{c}\text { Retrograde } \\
\text { pyelography+ } \\
\text { retropneumo } \\
\text { peritoneum }\end{array}$ & Aortography & $\begin{array}{c}\text { The estimated site } \\
\text { of the cavity }\end{array}$ \\
\hline $\mathbf{1}$ & 0 & 0 & 0 & L.m. \\
$\mathbf{2}$ & 0 & 0 & 0 & R.l. \\
$\mathbf{3}$ & 0 & 0 & 0 & L.u. \& 1. \\
$\mathbf{5}$ & 0 & 0 & 0 & L.u. \& 1. \\
$\mathbf{5}$ & 0 & 0 & 0 & L.l. \\
$\mathbf{7}$ & 0 & 0 & 0 & L.u. \\
$\mathbf{8}$ & 0 & 0 & L.u. \\
$\mathbf{9}$ & 0 & 0 & 0 & L.u. \\
$\mathbf{1 0}$ & 0 & 0 & 0 & L.u. \\
11 & 0 & 0 & L.u. & R.l.
\end{tabular}

*L.m.= left middle part, R. 1.=right lower pole,

L.u. \& 1.=left upper and lower poles, L. 1.=left lower pole, L.u.=left upper pole.

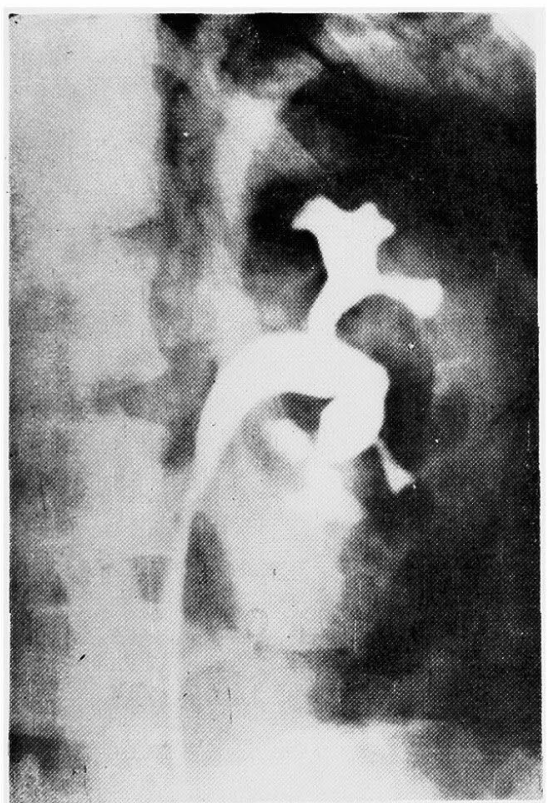

Fig. 3

Retrograde pyelogram with pneumoretroperitoneum in Case 1.

Auto-amputation of the middle calyces and blocking of the caudal major calyx are seen.

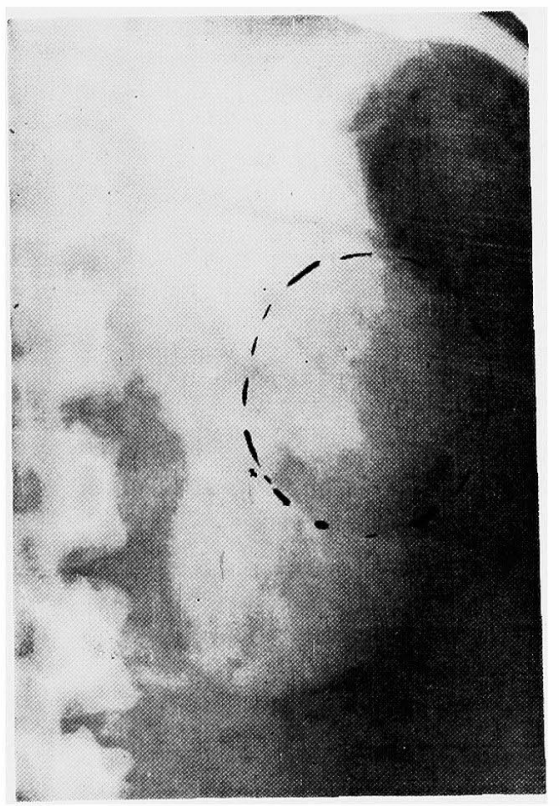

Aortogram of the Case. A poorly-outlined circular shadow is present on the middle pole. 


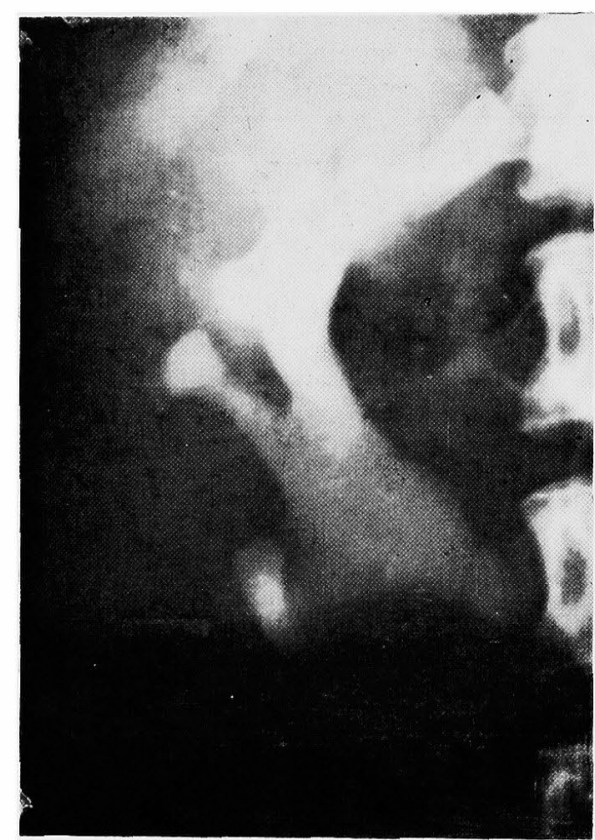

Fig. 4

Intravenous pyelogram in Case 11. The right lower calyx is compressed by a cavity in the lower pole.

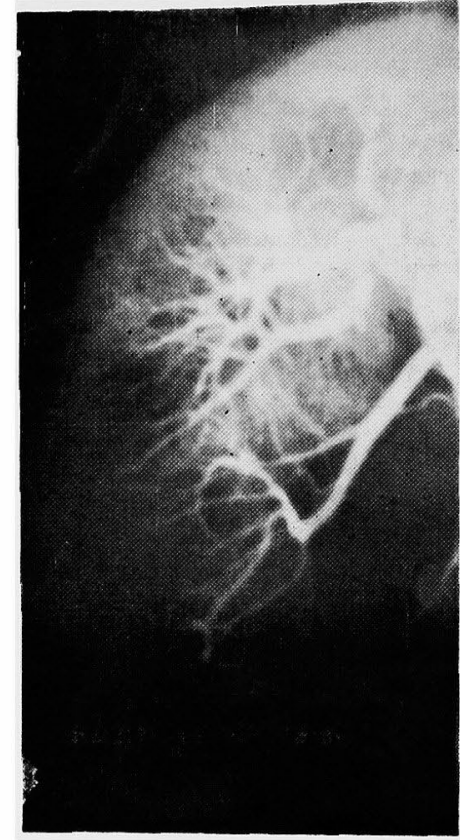

\section{Aortogram of the Case.}

The arteries running toward the lower pole are sparse and narrow. A poorly defined defect in the nephrogram is seen in the corresponding portion.

in many cases. Some cases complained of equivocal symptoms and some cases had no complaint at all. Case 1, for instance, complained of a dull pain in the right testicle, and Cases 8 and 10 had no complaint at all and renal tuberculosis was discovered by chance. The commonest complaint was discomfort or dull pain in the lumbar region, as in Cases 3, 4,5 and 7. Case 7, however, had ureteral stricture in the affected side together with renal tuberculosis.

\section{(3) Radiographic findings}

For x-ray examination, intravenous pyelography, retrograde pyelography combined with pneumoretroperitoneum, and aortography were employed. Judging from the operation findings the usability in diagnosis is shown in Table III. In all the cases intravenous pyelography was performed. When a cavity is suspected to be present, retrograde pyelography combined with pneumoretroperitoneum was carried out. The calyceal obliteration which was suspected on intravenous pyelography, was ascertained by the latter method in most cases. In addition, aortography, which was performed in 9 cases, revealed clearly 

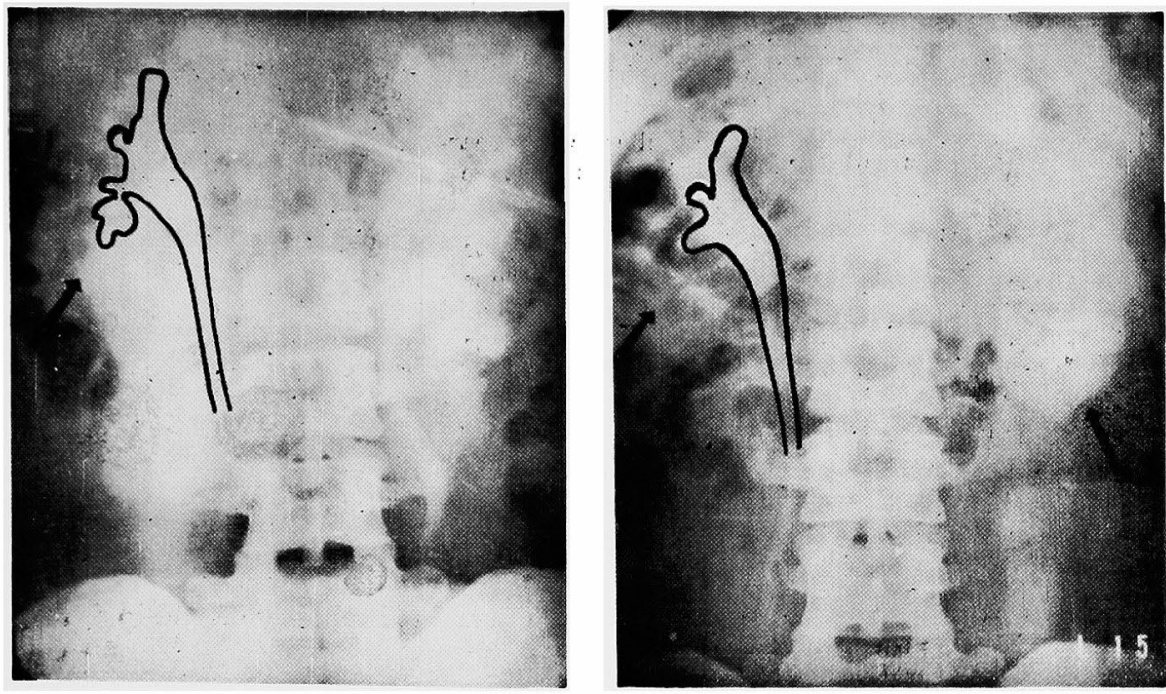

Fig. 5. Intravenous pyelogram in Case 2 .

Left: At the start of chemotherapy. Blocking of the lower branch of the pelvis with an irregular-margined dilatation of the lower calyces is seen.
Right: Three years and a half later. The lower calyces are amputated.

cavity in 6 cases (Cases 2, 4-7 and 10; Figs. 3 and 4). A selected case will be presented here to indicate how a cavity develops in the kidney: The left side picture in Fig. 5 is an intravenous pyelography taken at the beginning of the chemotherapy. It shows a stricture at the neck of the inferior major calyx and an irregularly margined dilatation in its peripheral minor calyces. Smear and culture of urine were positive for tubercle bacillus. One and a half years later, the dilated calyces turned invisible on pyelograms, and urine turned negative for tubercle bacillus. The intravenous pyelography in the right, which was taken immediately before the operation, shows a fully developed cavity.

(4) Urinalysis before and after the operation

The results of urinalysis before and 2-4 weeks after the operation are shown in Table IV. In preoperative period urine was turbid in 7 cases and clear in 4 cases. Microscopically, more than 10 white blood cells were found in a $4 \times 10^{2}$ field in 5 cases and more than 5 red blood cells in 5 cases. Tubercle bacillus was demonstrated in urine in only one case, Case 11. Generally speaking, urinary findings were not remarkably changed after the operation, although red and white cells in the urine disappeared in some cases. The tubercle bacilli, which were found in Case 11, disappeared from urine after the operation. In 4 cases (Cases 2, 4, 8, and 10) 
TaBLe IV. Results of Urinalysis

\begin{tabular}{|c|c|c|c|c|c|c|c|c|}
\hline \multirow[b]{2}{*}{ Case } & \multicolumn{4}{|c|}{ Pre-operative } & \multicolumn{4}{|c|}{ Post-operative } \\
\hline & $\begin{array}{l}\text { Appear- } \\
\text { ance }\end{array}$ & Pus cell & $\begin{array}{l}\text { Red } \\
\text { blood } \\
\text { cell }\end{array}$ & $\begin{array}{l}\text { Tubercle } \\
\text { bacillus }\end{array}$ & $\begin{array}{l}\text { Appear- } \\
\text { ance }\end{array}$ & Pus cell & $\begin{array}{c}\text { Red } \\
\text { blood } \\
\text { cell }\end{array}$ & $\begin{array}{l}\text { Tubercle } \\
\text { bacillus }\end{array}$ \\
\hline 1 & Turbid & + & - & - & Clear & - & - & - \\
\hline 2 & Clear & - & - & - & Olearr & - & - & - \\
\hline 3 & Turbid & - & + & - & Turbid & - & + & - \\
\hline 4 & Clear & - & - & - & Clear & - & - & - \\
\hline 5 & Turbid & - & + & - & Turbid & + & - & - \\
\hline 6 & Turbid & + & + & - & Turbid & + & - & - \\
\hline 7 & Turbid & + & + & - & Turbid & + & + & - \\
\hline 8 & Clear & - & - & - & Clear & - & - & - \\
\hline 9 & Turbid & + & - & - & Turbid & + & - & - \\
\hline 10 & Clear & - & - & - & Clear & - & - & - \\
\hline 11 & Turbid & + & + & + & Turbid & + & + & - \\
\hline
\end{tabular}

+ : More than 10 white blood cells or more than 5 red cells were found in a $4 \times 10^{2}$ field.

Table V. Renal Function before and after the Operation

\begin{tabular}{|c|c|c|c|c|c|c|}
\hline \multirow[t]{2}{*}{ Cases } & \multicolumn{2}{|c|}{$\begin{array}{l}\text { Initial time of indigo- } \\
\text { carmin excretion in } \\
\text { the affected side }\end{array}$} & \multicolumn{2}{|c|}{$\begin{array}{c}\text { P.S.P. } 30 \text {-minute } \\
\text { value }(\%)\end{array}$} & \multicolumn{2}{|c|}{$\begin{array}{l}\text { Serum N.P.N. } \\
(\mathrm{mg} / \mathrm{dl})\end{array}$} \\
\hline & Pre-oper. & Post-oper. & Pre-oper. & Post-oper. & Pre-oper. & Post-oper. \\
\hline 1 & $3^{\prime} 20^{\prime \prime}$ & $3^{\prime} 40^{\prime \prime}$ & 43 & 43.6 & 25.5 & 23.9 \\
\hline 2 & $4^{\prime} 12^{\prime \prime}$ & $4^{\prime} 10^{\prime \prime}$ & 41 & 43.1 & 26.7 & 26.7 \\
\hline 3 & $\begin{array}{l}\text { Not } \\
\text { examined }\end{array}$ & $\begin{array}{l}\text { Not } \\
\text { examined }\end{array}$ & $\begin{array}{l}\text { Not } \\
\text { examined }\end{array}$ & $\begin{array}{l}\text { Not } \\
\quad \text { examined }\end{array}$ & $\begin{array}{l}\text { Not } \\
\text { measured }\end{array}$ & $\begin{array}{l}\text { Not } \\
\quad \text { measured }\end{array}$ \\
\hline 4 & $3^{\prime} 45^{\prime \prime}$ & $3^{\prime} 50^{\prime \prime}$ & 25 & 25 & 24.3 & 35.7 \\
\hline 5 & $3^{\prime} 10^{\prime \prime}$ & $3^{\prime} 20^{\prime \prime}$ & 40 & 41 & 24.3 & 22.2 \\
\hline 6 & $5^{\prime} 30^{\prime \prime}$ & $4^{\prime} 50^{\prime \prime}$ & 30 & 42 & 25.6 & 28.2 \\
\hline 7 & $5^{\prime} 15^{\prime \prime}$ & $4^{\prime} 50^{\prime \prime}$ & 29 & 28 & 28.8 & 20.2 \\
\hline 8 & $3^{\prime} 60^{\prime \prime}$ & $3^{\prime} 45^{\prime \prime}$ & 42 & 43 & $\begin{array}{l}\text { Not } \\
\text { measured }\end{array}$ & $\begin{array}{l}\text { Not } \\
\text { measured }\end{array}$ \\
\hline 9 & $5^{\prime} 10^{\prime \prime}$ & $5^{\prime} 10^{\prime \prime}$ & 36 & 33 & 26.2 & 33.0 \\
\hline 10 & $4^{\prime} 50^{\prime \prime}$ & $4^{\prime} 30^{\prime \prime}$ & 45 & 42 & $\begin{array}{l}\text { Not } \\
\text { measured }\end{array}$ & $\begin{array}{l}\text { Not } \\
\text { measured }\end{array}$ \\
\hline 11 & $5^{\prime} 40^{\prime \prime}$ & $\begin{array}{l}\text { Not } \\
\text { examined }\end{array}$ & 12 & 15 & 62.7 & 47.0 \\
\hline
\end{tabular}

normal urinary findings persisted throughout the pre-and postoperative periods.

(5) Renal function

The renal function before and 1 month after the operation and at the time of 
discharge from the hospital was examined by measuring the initial time of indigocarmine excretion, PSP 30 minute value and the level of serum N.P.N. As shown in Table $\mathrm{V}$, postoperative improvement in renal function was seen in several cases: the initial time of the dye excretion improved slightly in 2 cases; P.S.P. excretion rate improved markedly in 1 case; and high preoperative level of serum N.P.N. decreased markedly in 1 case.

\section{(6) Operation findings}

The sites of the cavities diagnosed radiographically coincided perfectly with those found at operation, except for 1 case (Case 5). In most cases, however, more than two cavities were found at operation, although only one cavity was suspected on radiographic examinations (Table VI).

TABLE VI. Operation Findings

\begin{tabular}{|c|c|c|}
\hline Case & Method & Site and number of the cavities \\
\hline $\begin{array}{l}1 \\
2 \\
3 \\
4 \\
5\end{array}$ & Staehler's operation & $\begin{array}{l}\text { Right middle pole, } 1 \text { cavity } \\
\text { Left lower pole, } 3 \text { cavities } \\
\text { Left upper \& lower poles, several cavities } \\
\text { Left upper \& lower poles, several cavities } \\
\text { Left upper \& lower poles, several cavities }\end{array}$ \\
\hline $\begin{array}{r}6 \\
7 \\
8 \\
9 \\
10 \\
11\end{array}$ & Cavity-constriction & $\begin{array}{cl}\text { Left upper pole, } & \text { several cavities } \\
\prime \prime & , \text { several cavities } \\
\prime \prime & , \mathbf{3} \text { cavities } \\
" & , \text { several cavities } \\
" \prime & , 2 \text { cavities } \\
\text { Right lower pole, several cavities }\end{array}$ \\
\hline
\end{tabular}

(7) Period of preoperative chemotherapy, tubercle bacillus in the cavity, intracavitary ${ }^{131}$ I-hippuran excretion rate, persistence of postoperative fistula and their interrelation

The antituberculous chemotherapy which consisted mainly of three medicines, SM, PAS and Isoniazide, was carried out for 1 month to 5 years. As shown in Table VII, tubercle bacilli were demonstrated in a few cases, where a long-term chemotherapy was performed as well as in cases with short-term chemotherapy. In cases where a high intracavitary radioactivity of ${ }^{131}$ I-hippuran was detected, tubercle bacillus was absent in the cavity, while in cases in which low radioactivity was present, the bacilli were demonstrated.

As for the postoperative fistula which was formed at the place where the drainage tube was inserted, the period required for its closure was 8 to 9 days in 3 cases of 5 cases in which Staehler's operation was done. In one of the 5 cases fistula persisted for 75 days, and in another case (Case 5) it persisted for one and a half years with recurrent episodes of high fever (Fig. 6). In cases where 
Table VII. Period of Pre-operative Chemotherapy, Tubercle Bacillus in Cavity, Intracavitary I ${ }^{131}$-Hippuran Excretion Test and Persistence of Fistula

\begin{tabular}{|c|c|c|c|c|c|}
\hline Case & $\begin{array}{l}\text { Method of } \\
\text { operation }\end{array}$ & $\begin{array}{l}\text { Period of } \\
\text { pre-oper. } \\
\text { chemother. }\end{array}$ & $\begin{array}{l}\text { Tubercle } \\
\text { bacillus } \\
\text { in cavity }\end{array}$ & $\begin{array}{l}\text { Intracavit. } \\
\mathrm{I}^{\mathbf{1} 1} \text {-hippuran } \\
\text { excretion } \\
\text { (ratio to the } \\
\text { vesical urine) }\end{array}$ & $\begin{array}{l}\text { Persistence of } \\
\text { fistula }\end{array}$ \\
\hline $\begin{array}{l}1 \\
2 \\
3 \\
4 \\
5\end{array}$ & $\begin{array}{l}\text { Staehler's } \\
\text { operation }\end{array}$ & $\begin{array}{l}1 \text { month } \\
3 \text { yrs. } 6 \mathrm{~m} . \\
2 \text { yrs. } \\
1 \text { yr. } \\
2 \text { yrs. }\end{array}$ & $\begin{array}{l}\text { Positive } \\
\text { Negative } \\
\text { Positive } \\
\text { Negative } \\
\text { Negative }\end{array}$ & $\begin{array}{l}\text { Not examined } \\
1.2 \% \\
1.5 \\
3.3 \\
5.2\end{array}$ & $\begin{array}{l}2 \text { weeks } \\
2 " \text { " } \\
3 \text { " } \\
75 \text { days } \\
1 \text { yr. \& } 6 \mathrm{~ms} \text {. }\end{array}$ \\
\hline $\begin{array}{r}6 \\
7 \\
8 \\
9 \\
10 \\
11\end{array}$ & $\begin{array}{l}\text { Cavity- } \\
\text { constriction }\end{array}$ & $\begin{array}{l}3 \text { yrs. } \\
3 \text { yrs. } \\
3 \text { months } \\
2 \text { yrs. } \\
1 \text { yr. } \\
\text { ca. } 5 \text { yrs. }\end{array}$ & $\begin{array}{l}\text { Positive } \\
\quad " \prime \\
\quad " \prime \\
\text { Negative } \\
\text { Negative } \\
\text { Positive }\end{array}$ & $\begin{array}{c}1.2 \\
\text { Not examined } \\
1.4 \\
6.1 \\
1.4 \\
0\end{array}$ & 2 weeks \\
\hline
\end{tabular}
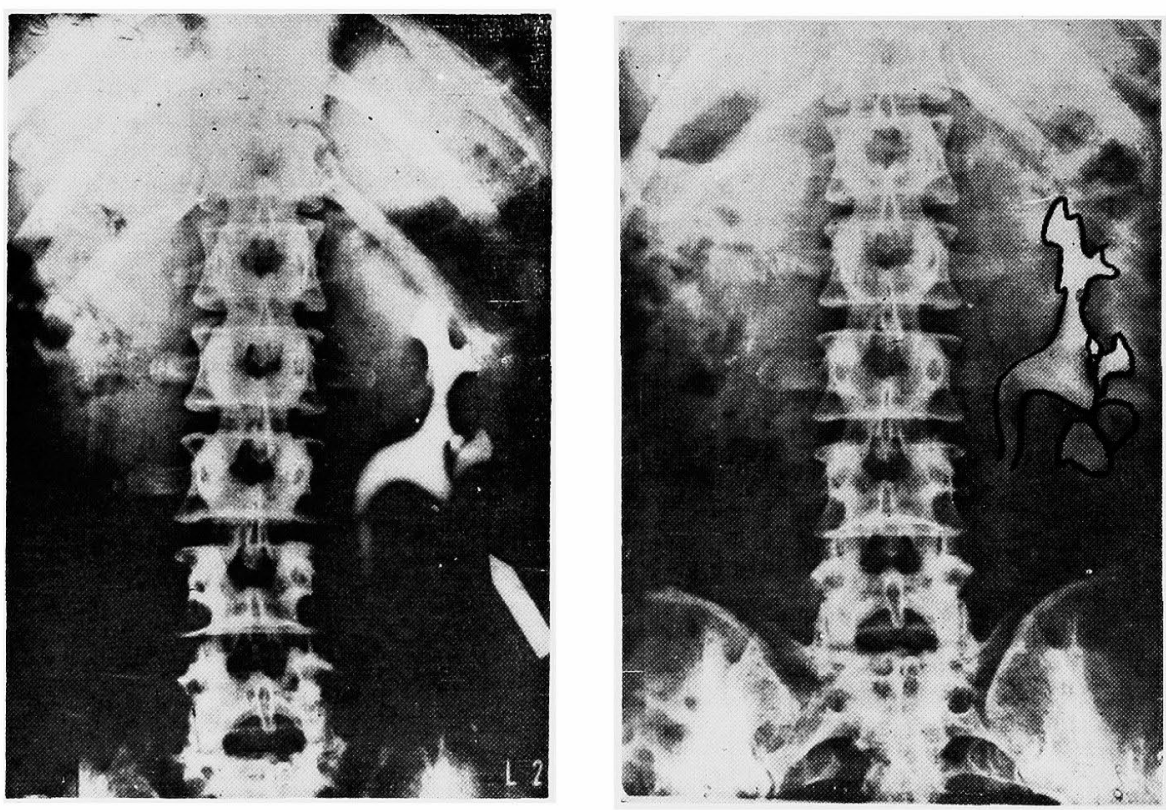

Fig. 6. Intravenous pyelogram in Case 5 .

Left: Taken immediately before the operation.

The left lower major calyx is obliterated.
Right: Taken about 11 months later. The lower calyces are delineated on the pyelogram, although there is a blocking seen at the lower major calyx.

cavity constriction was performed, the drainage discharge was considerably small in amount ( 5 to 10 c.c.), and the drainage tube was removed within 10 days. The 
fistula closed within 2 weeks after the operation in all cases. As seen in Table VII, a fistula persisted longer in cases in which a high intracavitary ${ }^{131}$ I-hippuran excretion rate was detected.

\section{DISCUSSION}

According to Staehler ${ }^{18,19}$ speleotomy is indicated to the closed cavity which has no communication with the renal pelvis. In our cases, however, the chief complaints were mostly non-specific such as discomfort or dull pain in the lumbar region. Some cases had no complaint at all and others showed normal urinalysis. Therefore, diagnosis of closed foci in the kidney should be relied on the $x$-ray examination. With this method, however, closed cavity is often overlooked. Staehler ${ }^{18,19}$ and Gunst ${ }^{8}$ stated that it could be discovered in the following way: In most cases, tuberculous stricture with hydro- or pyocalyces, is formed at the neck of a renal calyx which later changed into a cavity. Accordingly, when a calyx or calyces are not delineated on a urography, presence of a cavity can well be suspected. Sometimes, a cavity develops in the renal cortex, which compresses the renal calyces or pelvis, as in renal tumor or cyst. When a cavity is suspected on intravenous pyelogram, retrograde pyelography with pneumoretroperitoneum was useful for its identification. When defect of a calyx or deformation of a clayx or pelvis with wider parenchymal space is revealed, the presence of a cavity becomes definite. On the other hand, Gil-vernet et al. ${ }^{6}$ stated that periodical performance of renal angiography would often reveal a cavity. Ljunggren ${ }^{14}$ also reported that renal angiography was very useful for diagnosis of cavity in the kidney.

In all our cases, intravenous pyelography and retrograde pyelography combined with pneumoretroperitoneum was carried out. The former method was useful in making tentative diagnosis of a cavity in the kidney, and the latter was useful in making the diagnosis definite. Aortography, which was carried out in 9 cases, proved to be useful in determining the site of the cavity. In many cases roentgenographic findings coincided well with the operation findings, but, sometimes, a cavity could not be discovered by urographies as in Case 5 (Fig. 6). In this view it seems necessary to precisely observe the kidney, when it is exposed during operation. There is a problem concerning the cavity which is negative for tubercle bacillus. It is widely accepted that detectablity of the bacillus in the cavity is inversely proportional to the duration of the chemotherapy. On the other hand, Kairis ${ }^{12}$ reported that there was found out tubercule bacillus in a closed focus after a chemotherapy had been given for more than 10 years.

Ljunggren, ${ }^{14}$ Kanzler ${ }^{11}$ and many other investigators stated that the efficacy of chemotherapy depends more on the local renal function than on its duration. In other words, it is when chemotherapeutic agents reach the foci and disolve in the urine, that they can exert effects on them. In the present study the tubercle 
bacillus was found both in cases with comparatively short term chemotherapy and in the cases with a long-term one. This finding shows that chemotherapy of long duration is not always effective on a closed cavity in the kidney.

Therefore, we examined this problem by measuring intracavitary secretion rate of intravenously injected ${ }^{131}$ I-hippuran. In the eavities which were negative for tubercle bacillus high radioactivity was demonstrated, while radioactivity was low in the cavities which were positive for tubercle bacillus. Since the antituberculous agents were excreted in proportion to the renal function (Dick and Stevenson, ${ }^{4}$ Hoess et $a l^{10}$ ), it might well be considered that if a large quantity of hippuran is excreted into the cavity, the antituberculous agents would reach the foci in large quantity. When the blood stream around the recently-closed cavity was diminished, distribution of the agents could be disturbed. Accordingly, no matter how long the chemotherapy may be given, it is difficult to remove tubercle bacillus from the cavity. On these occasions speleotomy is indicated.

When relationship between the results of intracavitary ${ }^{131}$ I-hippuran excretion test and presence of tubercle bacilli in the cavity is discussed, the time which lapsed for formation of a cavity should also be taken into consideration. In Case 2, for instance, in which a cavity was demonstrated in the lower pole of the right kidney, the intracavitary concentration of radioactive hippuran was fairly low. Prior to the operation, the changes in roentgenographic findings were pursued for one and a half years after the commencement of chemotherapy. First, at the beginning of chemotherapy, the focus in the right lower pole was vaguely seen, indicating that the renal function was still maintained in that portion. One and a half years later urine turned negative for tubercle bacillus and, at the same time, the lower renal calyx became invisible on a pyelogram, indicating that a cavity was formed. In other words, after the foci were cleaned with the chemotherapeutic agents, "Kelchamputation" (autoamputation of the calyx at its neck) occurred and a cavity was formed (Fig. 5). Therefore, speleotomy could be unnecessary in this case. However, Staehler ${ }^{19}$ insisted on necessity of speleotomy even in these cases, because a tense cavity filled with caseous substance compresses the surrounding intact tissues and disturbs the blood supply to the compressed area.

In our cases, after speleotomy was performed, the renal function improved in many cases. This fact seems to support Staehler's opinion.

As mentioned above, speleotomy is an excellent method in many respects. When Staehler's operation is carried out, however, a fistula is often formed in the portion where a drainage tube was inserted during the operation. Steahler ${ }^{19}$ himself reported a case in which urinary fistula developed 2 weeks after the operation, and explained fistula-formation by stating that the operation was carried out to an open focus. Further, he added "the fistula would not have been formed, if the operation had been done on the closed cavity". This opinion does not 
seem logical. The classification by Staehler ${ }^{18,19}$ and many other investigators, by which the cavity is grouped into the open and closed ones, was based merely on roentgenographic findings. If the classification be right, we cannot explain the phenomenon that urine turned negative for tubercle bacillus after speleotomy. Therefore, it would be more logical to think thus. In this case there must have been fine communications between the cavity and the renal pelvis, although the cavity looked closed urographically. In our opinion, persistence of urinary fistula cannot be expected from the urographic findings, but it depends on the renal function remaining in the cavity wall. From this point of veiw, the cases in which Staehler's operation was carried out, were examined by intracavitary ${ }^{131}$ Ihippuran excretion test. As a result of this examination, a postoperative fistula was proved to persist longer in cases where higher intracavitary radioactivity was detected, that is, the cases whose cavity maintained secretion capacity. When Staehler's operation is performed to this cavity, the drainage tube becomes a sort of nephrostomy tube and the fistula cannot be expected to close in a short period. From these facts it seems that "cavity constriction" is more recommendable than Staehler's operation.

My grateful acknowledgments are made to Prof. S. Shishito for his kind guidance and careful review of the manuscript.

\section{References}

1) Aboulker, P. \& Wetterwald, F. Acta urol. belg., 1956, 24, 240.

2) Couvelaire, R. \& Auvert, J. Urol. int., 1958, 6, 91.

3) Couvelaire, R. J. Urol. med. chir., 1959, 65, 71.

4) Dick, J.C. \& Stevenson, J.S. Brit. J. Urol., 1952, 24, 179.

5) Frumkin, A.P. \& Buchmann, A.A. Zschr. Urol., 1960, 53, 479.

6) Gil-vernet, J.M., Fernändez, E. \& Gonzälez, V. Acta urol. belg., 1960, 28, 5.

7) Gloor, U. Schweiz. med. Wschr., 1960, 90, 513.

8) Gunst, W. Zschr. Urol, 1957, 50, 177.

9) Heitz-Boyer, M. J. Urol. med. chir., 1935, 39, 484.

10) Hoess, H., Lavener, H. \& Schönholzer, G. Urol. int., 1956, 3, 114.

11) Kanzler, W. Med. Mschr., 1959, 13, 589.

12) Kairis, Z. Urologia, 1960, 27, 130.

13) Ljunggren, E. Handbuch der Urologie, IX (2), p 1, Springer Verlag, Berlin, 1959.

14) Ljunggren, E. Med. J. Aust., 1960, 47, 322.

15) Rehn, E. Arch. klin. Chir., 1953, 276, 321.

16) Rehn, E. Medizinische, 1953, 337.

17) Staebler, W. Arch. klin. Chir., 1953, 276, 319.

18) Staehler, W. Medizinische, 1954, 943.

19) Staehler, W. Klinik und Praxis der Urologie, Georg Thieme Verlag, Stuttgart, 1959, p. 217. 